\title{
PENGELOLAAN PEMBELAJARAN IPA BERBASIS LINGKUNGAN DI SMPN 1 GABUS-GROBOGAN
}

\author{
Titik Setiyoningsih
}

SMPN 2 Gabus Grobogan

setyoningsiht@yahoo.com

\begin{abstract}
The purpose of this study are 1) to describe the planning of science learning based environment at SMPN 1 Gabus Grobogan 2) to describe the implementation of science learning based environment at SMPN 1 Gabus Grobogan 3) To describe the evaluation of curriculum science learning based environment at SMPN 1 Gabus Grobogan. The methodology of the study is qualitative. The design of the research is ethnographic. The techniques of data collections are (1) in-depth interviews (2) documentation (3) observation. This research focuses on description of data which kind of sentences that have profound meaning that comes from observed informants. And the techniques of data analysis are using (1)interlace or flow analysis model, and (2) interactive model. The validity of the data are using (1) Triangulation source (2) triangulation technique (3) Time triangulation. The result of study was the planning of science learning based environment which is begun by making the curriculum 2013 and then identify the subjects and the number of time lessons. By conducting the identification of science subjects, the lesson plans can be developed based on core competencies and basic competency in the curriculum.
\end{abstract}

Keywords: management, learning, environment, science

\begin{abstract}
ABSTRAK
Tujuan dari Penelitian ini adalah1) Mendiskripsikan perencanaanpembelajaran IPA berbasis lingkungan di SMPN 1 Gabus-Grobogan 2) Mendiskripsikan pelaksanaan pembelajaranIPAberbasislingkungandiSMPN1Gabus-Grobogan3)Mendiskripsikan evaluasi kurikulum IPA berbasis lingkungan di SMPN 1 Gabus-Grobogan. Metode yang digunakan dalam penelitian ini adalah kualitatif. Desain penelitiannya adalah etnografi.Teknik pengumpulan data dilakukan melalui (1) wawancara mendalam (2) dokumentasi(3) observasi. Jenis penelitian ini memusatkan pada deskripdi data yang berupa kalimat-kalimat yang memiliki arti mendalam yang berasal dari informan perilaku yang diamati.Sedang teknik analisis data menggunakan (1) model analisis jalinan atau mengalir dan (2) model analisis interaktif. Keabsahan data menggunakan (1) Triangulasi sumber (2) Triangulasi teknik (3) triangulasi waktu.Hasil penelitian ini adalah (1) perencanaan pembelajaran IPA Berbasis Lingkungan diawali dengan pembuatan kurikulum 2013 kemudian mengidentifikasi mata pelajaran dan jumlah jam pelajaran. Dengan mengadakan identifikasi mata pelajaran IPA maka RPP IPA dapat disusun dengan mengacu pada Kompetensi Inti dan Kompetensi Dasaryang ada
\end{abstract}


didalam kurikulum.Hasil penelitian menyimpulkan bahwa tidak semua kompetensi dapat direncanakan dengan menggunakan lingkungan. Perencanaan dengan menggunakan lingkungan disesuaikan dengan kebutuhan

Kata kunci : pengelolaan, pembelajaran, lingkungan, IPA

\section{PENDAHULUAN}

Dalam proses pembelajaran IPA di tingkat SMP/ MTs, secara umum IPA diajarkan meliputi bidang kajian energi dan perubahannya, bumiantariksa, makhluk hidup dan proses kehidupan, serta materi dan sifatnya. Energi dan perubahannya serta bumi antariksa dimasukkan ke dalam bidang fisika. Makhluk hidup dan proses kehidupannya termasuk dalam ilmu biologi. Sedangkan materi dan sifatnya digolongkan ke dalam ilmu kimia. Semua materi tersebut diajarkan pada siswa secara terpisah, sehingga siswa memahami konsep IPA secara terkotak - kotak berdasarkan disiplin ilmu dari objek yang dikajinya.

Lingkungan bagi manusia merupakan salah satu unsur yang penting dalam kehidupannya. Lingkungan ini bukan saja sebagai tempat manusia hidup, tetapi juga berperan dalam mendukung berbagai aktivitas manusia. Sikap dan perilaku manusia akan menentukan baik buruknya kondisi suatu lingkungan. Sebaliknya, bagaimana manusia memperlakukan lingkungan dampaknya akan berpengaruh terhadap kualitas kehidupan manusia itu sendiri (Hamzah, 2013).

Kenyataan dilapangan kemampuan siswa dalam memahami konsep IPA di SMP sekecamatanGabus-Grobogan masih rendah, hal ini disebabkan karena kurangnya pemahaman peserta didik terhadap materi yang disampaikan, masih monoton, ceramah sehingga hanya berangan-angan dalam proses pembelajaran.

Dengan terjun langsung dilingkungan sekitar,siswadapat dengan mudah menguasai konsep IPA karena siswa melakukan pengamatan pada situasi yang konkrit. Dampak positif dari pendekatan lingkungan yaitu siswa dapat terpacu sikap rasa keingintahuannya tentang sesuatu yang ada dilingkungannya.Peserta didik akan merasa lebih tertantang karena peserta didik berhadapan langsung dengan obyek nyata. Dalam pembelajaran berbasis alam dan lingkungan, siswa tidak hanya memahami materi yang diberikan oleh guru dalam ceramah secara abstrak, tetapi siswa dapat melihat langsung ke alam dan lingkungan sekitar, misalnya siswa dapat diajak melihat langsung peristiwa yang ditimbulkan oleh alam dan dampaknya terhadap manusia serta lingkungan. Contoh siswa dapat belajar mengatupnyadaun putri malu apabila kita sentuh, siswa dapat mempelajari bagian-bagian bunga, penyebab terjadinya sungai yang kotor, penyebab banjir, sambungan rel yang merapat pada siang hari, tumbuhan jati yang meranggas pada musim kemarau.Dalam pembelajaran tersebut siswa dapat melihat secara nyata, dengan demikian siswa selalu mengingatnya.

Menurut pengamatan peneliti, guru IPA di SMPN 1 Gabus telah menggunakan model pembelajaran yang bervariasi termasuk telah menggunakan model pembelajaran IPA berbasis Lingkungan, karena SMP ini dikelilingi oleh sawah, kebun sekolah, taman bunga didepan kelas, dekat dengan rel kereta api, terminal dan hutan walaupun tidak lebat.Selain itu SMPN 1 
Gabus juga memiliki laboratorium IPA yang lengkap dan memiliki nilai rata-rata IPA terbaik untuk ujian nasionalnya, dibandingkan dengan sekolah negeri dan swasta disekitarnya.

Tujuan Penelitian ini adalah untuk mendiskripsikan perencanaan pembelajaran, pelaksanaan pembelajaran dan evaluasi kurikulum IPA di SMPN 1 Gabus-Grobogan.

Budiyono Saputro ( 2012 ) melaporkan bahwa dalam lingkungan belajar ilmu pengetahuan alamsiswa dapat belajar ilmu pengetahuan melalui pengalaman langsung.Lingkungan danpembelajaran berbasis alam diharapkan dapat mengubah paradigma, bahwa kualitas sekolah tidak selalu mahal. Untuk menggantiparadigma ini diperlukan sistem pendidikan yang berkualitas dan terjangkau, tidak bergantung pada alat peraga yang mahal, tetapi mengacu padaalam dan lingkungan sebagai sumber pengetahuan.

Mia Cholvistari ( 2012 ) melaporkan bahwa dalam pembelajaran biologi berbasis lingkungan sangat membantu seorang guru menyampaikan materi-materi dan memberikan dampak positif bagi siswa karena mengembangkan ketrampilan sains dan hasil belajar siswa.

Hasil Penelitian Higgins ( 2005 ) menyatakan bahwa tujuan utama dari belajar berbasis lingkungan adalah untuk menghadapi tantangan zaman dan para siswa serta guru terlibat dalam kepemimpinan, desain, perencanaan, sumber daya manajemen sekolah untuk menyediakan lingkungan belajar yang inovatif dan efektif ini bersifat menyeluruh untuk mencapai keberhasilan.

Penelitian Najulmunir ( 2010 ), mengatakan bahwa lingkungan sekolah dapat dimanfaatkan sebagai sumber belajar, seperti kebun sekolah, masyarakat, halaman sekolah. Guru dapat memanfaatkan lingkungan sekolah untuk memudahkan siswa dalam memahami materi yang diajarkan. Khusus untuk pelajaran IPA Fisika, Biologi Kimia dan geografi, dapat memanfaatkan lingkungan sebagai media pembelajaran. Dengan memanfaatkan lingkungan proses pembelajaran menjadi sangat efektif.

Juli Ernes ( 2013 ) menyatakan dalam penelitiannya bahwa adanya peningkatan dukungan guru di Washington dalam menerapkan pendidikan berbasis lingkungan dalam pendidikan formal. Para guru tersebut menunjukkan bukti hasil pembelajaran siswa meningkat dalam bidang membaca, matematika dan ilmu pengetahuan.Pembelajaran berbasis lingkungan mampu membuat siswa berpikir kritis, meningkatkan motivasi dan kemampuan memecahkan masalah.

\section{METODE}

Pendekatan penelitian yang digunakan dalam penelitian ini adalah pendekatan kualitatif (qualitative research).Bogdan dan Taylor (Moleong, 2006: 4) mendefinisikan metodologi kualitatif sebagai prosedur penelitian yang menghasilkan data deskriptif berupa kata-kata tertulis atau lisan dari orang-orang dan perilaku yang dapat diamati.

Sutama ( $2010: 282$ ) menyatakan penelitian kualitatif adalah penelitian yang ditujukan untuk mendiskripsikan dan menganalisis fenomena-fenomena ,peristiwa dan aktifitas social secara alamiah.

Jadi penelitian deskriptif kualitatif adalah penelitian yangmendeskripsikan serta memaparkan data berdasarkan fakta yang ada dalambentuk kata-kata dan bahasa, kemudian dilanjutkan dengan analisis data yangtidak didesain atau dirancang menggunakan prosedur statistic. 
Penelitian ini menggunakan pendekatan etnografi. Studi etnografi (ethnographicstudies) mendeskripsikan dan menginterpretasikan budaya, kelompok sosial atau sistem.Meskipun makna budaya itu sangat luas, tetapi studi etnografi biasanya dipusatkan pada pola-pola kegiatan, bahasa, kepercayaan, ritual dan cara-cara hidup (Sukmadinata, 2006: 62).

Lokasi penelitian ini di SMPN 1 Gabus-Grobogan SMPN 1 Gabus berdiri sejak tahun 1970 dan terletak di kota kecamatan. Dari arah jalan raya Gabus- Blora masuk kurang lebih berjarak $1 \mathrm{~km}$. Jumlah guru 52 yang terdiri dari 45 PNS dan 7 GTT.

Prosedur Penelitian ini dibagi dalam dua tahap. Pertama tahap perencanaan, peneliti menyiapkan hal-hal yang berkaitan dengan perlengkapan yang dibutuhkan dalam penelitian. Kedua tahap pelaksanaan, penelitian diawali dengan mengurus proses perijinan pada sekolah yang akan diteliti. Setelah mendapatkan ijin, peneliti mengumpulkan data hingga mendapatkan data yang dibutuhkan.

Dalam penelitian ini peneliti menggunakan sumber data berupa hasil observasi, hasil wawancara dan dokumentasi. Nara sumber dalam penelitian ini adalah Kepala sekolah, Kurikulum, Guru IPA dan siswa dilingkungan SMPN 1 Gabus-Grobogan.

Teknik Pengumpulan data pada penelitian ini adalah wawancara mendalam, pengamatan/ observasi dan dokumentasi.Didalam melakukan analisis data peneliti mengacu pada tahapan yang dijelaskan oleh Mile dan Huberman ( 2007 ) yang terdiri dari tiga tahapan yaitu reduksi data , penyajian data dan penarikan kesimpulan. Untuk menetapkan keabsahan data diperlukan teknik pemeriksaan yang didasarkan atas kriteria 1) dejat kepercayaan ( credibility ), 2) keteralihan ( trasferability) 3) ketergantungan ( dependability ) 4) kepastian ( confirmability ).

\section{HASIL DAN PEMBAHASAN}

\section{Perencanaan pembelajaran IPA berbasis lingkungan}

Hasil analisis data dari penyiapan kurikulum 2013 di SMPN 1 Gabus menunjukkan bahwa penyusunan Kurikulum 2013 merupakan kerjasama dari tim pengembang kurikulum yang terdiri dari Kepala Sekolah, Wakil Kepala Sekolah, seksi Kurikulum dan guru. Penyusunan tersebut berpedomaan pada Standar isi dan Standar Kelulusan.

Dalam tahap perencanaan ini, guru mempersiapkan program tahunan (Prota), Program Semester (Promes), Silabus dan Rencana Pelaksanaan Pembelajaran (RPP). Persiapan prota dan promes dimaksudkan agar guru bisa memprogram/menjadwal pembelajaran secara teratur dan terencana sejak awal. Persiapan perencanaan prota dan promes biasanya dilakukan diawal tahun ajaran (awal semester).

Prota disusun sendiri oleh guru yang menjelaskan alokasi waktu, yang digunakan untuk mencapai KI dan KD dalam satu tahun berdasarkan kaldik yang ada dari Pemerintah yang sudah diolah dan disesuaikan program sekolah setelah itu baru dituangkan kedalam kaldik sekolah.Promes merupakan penjabaran dari silabus yang berisikan tentang Indikator, alokasi waktu dan sebaran materi pokok yang hendak dicapai tiap semesternya.

Setelah perumusan prota dan promes, guru IPA juga mempersiapkan silabus. Silabus ini berisi pokok bahasan yang harus disampaikan pada pembelajaran. Silabus ini meliputi standar kompetensi, kompetensi dasar, indicator pembelajaran, metode pembelajaran, alokasi waktu pertemuan, metode pembelajaran, evaluasi, bahan ajar dan sumber belajar.

Silabus disusun berdasarkan kurikulum 2013, yang disesuaikan dan dikembangkan 
dengan karakteristik mata pelajaran dan kondisi sekolah. Dalam pengembangan silabus perlu mengkaji kompetensi inti dan kompetensi dasar yang ada, merumuskan indikator pencapaian kompetensi. Silabus yang telah dikembangkan oleh guru dalam RPP telah terintegrasi dengan lingkungan yang ada disekitar sekolah.Bahan ajar dalam rencana pelaksanaan pembelajaran menggunakan lingkungan sebagai tempat pembelajarannya dengan menggunakan kuadran.

Perencanaan pembelajaran IPA dengan memanfaatkan ligkungan sekolah sebagai sumber belajar disusun dalam bentuk Rencana Pelaksanaan Pembelajaran ( RPP ) dengan mengacu pada kurikulum 2013 yang memuat identitas, kompetensi inti, Kompetensi Dasar, Indikator, Tujuan Pembelajaran, Materi pembelajaran, pendekatan /Strategi/metode pembelajaran, media/alat dan sumber belajar, langkah-langkah pembelajaran, penilaian ( cognitive, afektif dan psikomotor).

Seperti yang dikemukakan oleh Majid ( 2008:16 ) bahwa perencanaan pembelajaran merupakan proses yang sistematis dalam pengambilan keputusan terhadap tindakan pembelajaran yang akan dilakukan.

Pada dasarnya perencanaan pembelajaran merupakan sebuah rancangan atau persiapan yang dibuat oleh guru tentang pembelajaran yang menjadi tanggungjawabnya.Perencanaan pembelajaran merupakan proyeksi dari proses pelaksanaan pembelajaran, menggambarkan apa yang diperlukan dalam rangka mencapai tujuan pembelajaran. Perencanaan pembelajaran merupakan pedoman bagi guru dalam pelaksanaan pembelajaran, dan merupakan pedoman belajar bagi siswa.

Melalui perecanaan pembelajaran dapat diidentifikasi apakah pembelajaran yang dikembangkan sudah menerapkan konsep belajar siswa aktif atau mengembangkan ketrampilan proses.

Fungsi perencanaan pembelajaran sebagai proyeksi tindakan, seperti yang dikemukakan oleh Sujana ( 2008 ), yang mengemukakan bahwa pembelajaran merupakan kegiatan memproyeksikan tindakan apa yang akan dilaksanakan dalam suatu pembelajaran, mengandung arti bahwa perencanaan pembelajaran yang disusun oleh guru hendaknya selalu berpedoman pada pencapaian tujuan pembelajaran yang efektif dan efisien. Maka sangatlah tepat jika RPP yang dikembangkan oleh guru memanfaatkan lingkungan sekolah sebagai sumber belajar.

Berdasarkan uraian diatas dapat dikemukakan bahwa RPP dengan memanfaatkan lingkungan sekolah sebagai sumber belajar yang disusun oleh guru menunjukkan bahwa guru IPA menyadari betul bahwa lingkungan sekolah sangat dibutuhkan oleh siswa dalam proses pembelajaran. Lingkungan sekolah dapat memberikan kontribusi terhadap motivasi belajar dan keterlibatan siswa dalam proses belajar mengajar. Jika dibandingkan dengan hasil penelitian yang dilakukan oleh Reed (,2008) maka sama-sama menunjukkan bahwa "siswa lebih menyukai belajar ditempat dengan suasana baru, termasuk digedung baru. Dengan suasana baru sikap siswa dalam mengikuti pembelajaran lebih positif ".

\section{Pelaksanaan pembelajaran IPA berbasis lingkungan}

Hasil analisis data dalam pelaksanaan pembelajaran IPA berbasis lingkungan di SMPN 1 Gabus menunjukkaan bahwa pada awal pembelajaran berlangsung diawali dengan kegiatan pendahuluan meliputi mengucapkan salam motivasi dan apresepsi. 
Guru menyampaikan tujuan pembelajaran yang akan dicapai begitu juga dengan materinya. Tujuan pembelajaran pada kegiatan pembelajaran itu adalah mengidentifikasi komponen biotic dan abiotik dengan melakukan pengamatan.

Strategi dan model pembelajaran yang tercantum dalam kurikulum IPA dapat mendorong minat dan aktifitas siswa untuk belajar. Metode pembelajaran guru yang digunakan adalah 1) Metode ekspositori ( menerangkan ), 2) Tanya jawab 3) Demontrasi 4) Praktek langsung dilingkungan sekolah.

Materi ajar adalah substansi yang disampaikan pengajar dalam proses belajar mengajar. Materi ajar dipilih berdasarkan tujuan pembelajaran dan kompetensi yang ingin dicapai. materi yang disampaikan disesuaikan dengan kebutuhan siswa serta tuntutan perkembangan jaman, materi juga dihubungkan dengan konteks kehidupan sehari-hari, sehingga siswa dapat menerapkan dalam kehidupan sehari-hari. Sumber bahan ajar yang digunakan meliputi : buku paket, LKS, Modul dan buku lain yang menunjang materi tersebut.

Hal ini didukung oleh hasil penelitian Hamalik ( 2005 ) yaitu teknik-teknik pembelajaran Biologi Berbasis Lingkungan dapat diterapkan sebagai berikut : a) fieldtrip atau fieldst udy yaitu siswa diajak mengunjungi tempat tertentu yang relevan dengan tujuan pembelajaran. b) Siswa secara langsung mencoba mengembangkan potensinya dalam bentuk ketrampilan misalnya membuat tempe, tahu, dan makanan c) perkemahan yaitu siswa diajak oleh guru untuk menyelami alam sekitar, misalnya iklim, suhu, udara d) siswa diajak survey suatu tempat yang relevan dengan tujuan pembelajaran e) guru dapat mengajak siswa melakukan kegiatan kemasyarakatan yang sifatnya sederhana sesuai dengan tingkat kemampuan siswa misalnya kebersihan lingkungan, gotongroyong dan pembelajaran yang bersifat social.

Hasil analisis ini bila dibandingkan dengan penelitian Juli Ernes ( 2013 ) menyatakan dalam penelitiannya bahwa adanya peningkatan dukungan guru di Washington dalam menerapkan pendidikan berbasis lingkungan dalam pendidikan formal. Para guru tersebut menunjukkan bukti hasil pembelajaran siswa sama-sama meningkat dalam bidang membaca, matematika dan ilmu pengetahuan. Pembelajaran berbasis lingkungan mampu membuat siswa berpikir kritis, meningkatkan motivasi dan kemampuan memecahkan masalah.

Media merupakan alat pembelajaran yang digunakan guru untuk membantu mempermudah memahami materi yang disampaikan dalam pembelajaran. Berdasarkan hasil wawancara, observasi dan dokumentasi menyatakan bahwa guru IPA di SMPN 1 Gabus dalam pembelajarannya sudah menggunakan media pembeajaran yang bervaruiatif dan memanfatkan lingkungan atau benda-benda sekitar yang berkaitan dengan materi. Media yang digunakan masih sederhana yaitu gambar, poster, LCD power point dan kuadran, sesuai apa yang disampaikan oleh Arsyad ( 2005 ) bahwa jenis media pembelajaran dapat berupa a) media proyeksi seperti LCD, power point, video, b) media grafis misalnya gambar, foto, poster c) media model misalnya manusia, hewan, tumbuhan d) media informasi misalnya computer, internet e) media lingkungan misalnya sawah, kolam dan lain-lain.

Hal-hal unik yang terjadi selama proses pembelajaran adalah, beberapa siswa sangat asyik mengamati benda-benda yang ada disekitarnya, mengerjakan latihan bersama teman teman satu kelompoknya untuk menyelesaikan tugasnya.

Hasil analisis ini bila dibandingkan dengan penelitian Mia Cholvitasari 2012 "bahwa dalam pembelajaran biologi berbasis lingkungan sama-sama sangat membantu seorang 
guru menyampaikan materi-materi dan memberikan dampak positif bagi siswa karena mengembangkan ketrampilan sains dan hasil belajar siswa. Kegiatan pemanfaatan lingkungan bertujuan untuk mengembangkan ketrampilan sains dan hasil belajar siswa karena dapat menciptakan suasana pembelajaran yang lebih menarik dan menarik efektif dan efisien”.

Evaluasi pembelajaran yang dilakukan meliputi penilaian kognitif, afektif dan psikomotor. Pada kognitif dilaksanakan dalam bentuk tes tertulis dan tugas, afektif yaitu penilaian sikap dan psikomotorik penilaian ketrampilan. Bentuk evaluasi pembelajaran yang dilaksanakan adalah ulangan harian per KD, UTS ( Ulangan Tengah Semester), UAS gasal dan genap, setelah dilaksanakan evaluasi, selanjutnya nilai tersebut dianalisis, bagi siswa yang sudah sesuai atau melebihi KKM akan mengikuti program pengayaan atau pendalaman materi, sedang yang kurang dari KKM akan mengikuti program remidi. Evaluasi inti bertujuan untuk mengukur ketercapaian tujuan pembelajaran dan menindaklanjuti hasil yang telah diperoleh.

Hal ini mengacu pada permendiknas no .22 tahun 2006. Dimensi penilaian yang digunakan dalam pembelajaran meliputi dimensi pengetahuan, dimensi ketrampilan, dan dimensi nilai-nilai/sikap. Penilaian ranah pengetahuan dilakukan dengan tes. Penilaian ranah ketrampilan dan nilai-nilai/sikap dilakukan dengan prosedur sebagai berikut : a) menentukan aspuk ketrampilan atau nilai-nilai yang diintegrasikan b) merancang metode pembelajaran dengan mengintegrasikan ketrampilan atau nilai-nilai tersebut c) merumuskan indikator pencapaian aspek ketrampilan dan nilai-nilai yang diintegrasikaan d) menetapkan tingkat pencapaian setiap indikator, e) menetapkan skor tiap-tiap tingkatan f) menyusun rubrik. Jadi obyek penilaian pembelajaran IPA mencakup penilaian proses dan hasil belajar siswa. Penilaian dilakukan guru ketika siswa melakukan kegiatan pengamatan,diskusi, mengerjakan tugas, presentasi dan pada awal pembelajaran sampai akhir pembelajaran. Hal ini sesuai dengan pendapat Djamarah ( 2009:245 ) yang menyatakan bahwa "Aspek penting lain dalam pengelolaan pengajaran adalah evaluasi atau penilaian. Evaluasi atau penilaian dalam pengajaran tidak semata-mata dilakukan terhadap hasil belajar, tetapi juga harus dilakukan terhadap proses pengajaran itu sendiri.

\section{Evaluasi Kurikulum IPA Berbasis Lingkungan di SMPN 1 Gabus-Grobogan}

Evaluasi kurikulum IPA Berbasis Lingkungan yang bertujuan untuk mengevaluasi sejauh mana program-program pembelajaran telah terselesaikan. . Seperti yang disampaikan oleh Din Wahyudin ( 2014 ) bahwa Evaluasi kurikulum dimaksudkan untuk memeriksa kinerja kurikulum secara keseluruhan ditinjau dari berbagai criteria.Indikator kinerja yang dievaluasi adalah efektifitas, efesiensi, relavansi, kelayakan program . Evaluasi kurikulum IPA dilaksanakan tiap akhir tahun oleh Kepala Sekolah.

Hasil evaluasi menunjukkan bahwa kurikulum IPA Berbasis Lingkungan sudah baik dan sesuai dengan kebutuhan siswa. Evaluasi terhadap setiap program yang diajarkan guru dikelas sudah sesuai dengan yang ditetapkan dikurikulum. Hasil evaluasi kurikulum dijadikan sebagai pedoman untuk panduan dalam pengembangan kurikulum tahun berikutnya. Evaluasi kurikulum dilakukan secara mikro. Model yang digunakan untuk evaluasi kurikulum IPA Berbasis Lingkungan yaitu dengan dilakukannya observasi oleh kepala sekolah dikelas atau supervise akademik dan pengecekan kepala sekolah terhadap semua administrasi yang harus dibuat oleh seorang guru. 
Evaluasi kurikulum ini didukung oleh penelitian Sarlita Dewi dkk ( 2014 ), mengatakan cara mengetahui analisis kesiapan kurikulum 2013 di Sd dikota Pekalongan, yaitu dengan menggunakan instrument yang disusun dengan merujuk pada PP no 32 tahun 2013 sebagai payung hokum, dan teknis pelaksanaannya pada permendbud no 67 tentang kerangka dasar kurikulum 2013, Permendikbud no 65 tentang proses pembelajaran. Permendikbud no 54 tentang standar kompetensi kelulusan dan Permendikbud no 66 tahun 2013 tentang standar penilaian pendidikan.

Hasil evaluasi kurikulum menunjukkan bahwa tujuan dan kompetensi sudah sesuai yang tercantum dalam visi dan misi sekolah. Tujuan dan kompetensi ini mudah dipahami guru, dan sudah sesuai dengan tingkat perkembangan siswa. Hal ini sesuai dengan penelitian yang dilakukan oleh Hussain ( 2011 ) dengan judul "Evaluation of Qurikulum Development Prosess" Inti dari pencapaian kurikulum tergantung pada proses evaluasi selama pengembangan.

\section{PENUTUP}

Berdasarkan hasil penelitian yang telah disajikan dalam Bab IV mengenai karateristik pengelolaan pembelajaran IPA di SMPN 1 Gabus-Grobogan dapat disimpulkan beberapa hal sebagai berikut :

1. Perencanaan Pembelajaran IPA Berbasis Lingkungan di SMPN 1 Gabus-Grobogan.

Perencanaan pembelajaran IPA diawali dengan penyusunan kurikulum yang dilakukan oleh Wakil Kepala Sekolah, Sie kurikulum. dan guru yang ditunjuk. Mereka membuat program-program sekolah setelah itu baru membuat rincian waktu dengan mengacu pada kaldik yang dibuat pemerintah. Untuk membuat prota dan promes alokasi waktu dibuat berdasarkan kaldik dan jumlah jam mengajar tiap minggunya. Jadi Prota dan promes dibuat sendiri oleh guru yang bersangkutan. Perencanaan selanjutnya adalah membuat silabus yang dikembangkan oleh setiap guru yang menyesuaikan karakteristik sekolah dan sudah terintegrasi dengan lingkungan.

Hasil penelitian menyimpulkan bahwa tidak semua kompetensi dasar direncanakan dengan menggunakan lingkungan sebagai proses pembelajarannya. Karena tidak semua KD materinya menggunakan lingkungan. Pembuatan RPP yang terintegrasi dengan lingkungan bisa dibuat jika materinya memerlukan lingkungan sebagai proses pembelajarannya.

2. Pelaksanaan Pembelajaran IPA Berbasis Lingkungan di SMPN 1 Gabus-Grobogan.

Pelaksanaan pembelajaran IPA yang berbasis lingkungan diawali dengan apersepsi, motivasi dan penyampaian tujuan pembelajaranMetode pembelajaran guru yang digunakan adalah 1) Metode ekspositori ( menerangkan ), 2) Tanya jawab 3) Demontrasi 4) Praktek langsung dilingkungan sekolah.

Materi Pembelajaran didiskripsikan oleh guru sebelum siswa berada diluar kelas sehinggga siswa focus pada guru. Materi ajar dipilih berdasarkan tujuan pembelajaran dan kompetensi yang ingin dicapai.materi yang disampaikan disesuaikan dengan kebutuhan siswa serta tuntutan perkembangan jaman , materi juga dihubungkan dengan konteks kehidupan sehari-hari, sehingga siswa dapat menerapkan dalam kehidupan sehari-hari. Sumber bahan ajar yang digunakan meliputi : buku paket, LKS, Modul dan buku lain yang menunjang materi tersebut.Guru IPA di SMPN 1 Gabus dalam pembelajarannya sudah menggunakan 
media pembeajaran yang bervaruiatif dan memanfatkan lingkungan atau benda-benda sekitar yang berkaitan dengan materi. Media yang digunakan masih sederhana yaitu gambar, poster, LCD power point dan kuadran.

3. Evaluasi Kurikulum IPA Berbasis Lingkungan di SMPN 1 Gabus-Grobogan.

Evaluasi kurikulum adalah kegiatan memberikan penilaian terhadap sukses tidaknya kurikulum yang digunakan. Semua guru telah melaksanakan diklat atau workshop kurikulum 2013. Selain itu terdapat tiga guru yang menjadi Instruktur Nasional Kurikulum 2013. Melalui hasil obeservasi supervisi akademik dan kroscek semua administrasi guru maka diketahui evaluasi kurikulum di SMPN 1 Gabus telah dilaksanakan dengan baik dibuktikan kurikulumsudah sesuai dengan kebutuhan siswa, sesuai visi dan misi sekolah, selain itu supervisi akademik terhadap guru IPA oleh kepala sekolah dikelas dengan penilaian baik .

\section{DAFTAR PUSTAKA}

Budiyono Saputro. 2012. Inovasi Pembelajaran Sains Berbasis Alam dan lingkungan.

Hamzah.2007. Manajemen Teori Praktek dan Riset Pendidikan . cetakan ke 1.Jakarta : Bumi Aksara

Hartadi.2014. Pembelajaran Kontektual dengan Memanfaatkan Lingkungan Sebagai Sumber Belajar.

Higgin. 2015. “ The Impact of school Environments a literature Review the Learning hours vol 170.

Julie Ernst.2014."Early Childhood Educators Preferences and Perceptions Regarding Outdoor Setting as learning Environments International Journal of Early Childhood Environmental Education," 2 (1).

Mia Cholvitasari.2012 "Penetapan Model Pembelajaran Berbasis Lingkungan Dalam Upaya Meningkatkan Ketrampilan Proses Sains Siswa SMA Metro"

Moleong, Lexy. 2012. Metodelogi Penelitian Kualitatif. Bandung : Remaja Rosda Karya.

NajulMunir.2010.Memanfaatkan Lingkungan Sekolah Sebagai Pusat Sumber Belajar.

Sarlita Dewi, 2014.M.Pd. "Evaluasi Pelaksanaa Kurikulum 2013 Tingkat Satuan Pendidikan Dasar/Sekolah Dasar di Kota Pekalongan".

Sutama.2012. Metode Penelitian Pendidikan. Kartosura: Fairus media.

Sukmadinata.2006. Metode Penelitian Pendidikan. Bandung: Remaja Rosda Karya.

Sanjaya Wina. 2010. Kurikulum dan Pembelajaran. Jakarta : Prenada.

Sukmadinata, S.2006. Metode Penelitian Pendidikan: Bandung:Remaja Rosda Karya. 